\title{
ANTIBIOTIKA RASIONAL DALAM ILMU BEDAH
}

\author{
Mochamad Aleq Sander \\ Fakultas Kedokteran Universitas Muhammadiyah Malang \\ e-mail: aleq.sander@yahoo.com blog: bedahunmuh.wordpress.com
}

\begin{abstract}
Utilizing of antibiotics to cure operation infection actually not differ from gift antibiotics in general. The difference was antibiotic treatment be addition therapy after surgery. The aim of antibiotics treatment was prevent or cure infection by reducing or eliminating bacteria until human body can handle this pathogenic organism.
\end{abstract}

Keywords: rational antibiotic, infection, surgery

\begin{abstract}
ABSTRAK
Penggunaan antibiotika untuk mengobati infeksi operasi sebenarnya tidak berbeda dengan pemberian antibiotika pada umumnya. Perbedaannya ialah bahwa terapi antibiotika merupakan terapi tambahan setelah terapi utama pembedahan.

Tujuan pemberian terapi antibiotika adalah untuk mencegah atau mengobati infeksi dengan cara menurunkan atau mengeliminasi bakteri sampai daya tahan tubuh sendiri dapat mengatasi organisme patogen ini.
\end{abstract}

Kata kunci: antibiotika rasional, infeksi, pembedahan

\section{Pendahuluan}

Pengobatan secara rasional, efektif dan aman sebetulnya harus berlaku untuk semua tindakan pengobatan yang dilakukan oleh profesi kedokteran dan tidak hanya terbatas pada penggunaan antibiotika. Rasional berarti bahwa diagnosis penyakit harus ditentukan dengan tepat sehingga pemilihan obat dapat dilakukan dengan tepat dan mengenai sasarannya dengan efek samping seminimal mungkin.

Hal utama yang perlu mendapat perhatian pada pemberian antibiotika ini adalah efektivitas, toksisitas, dan harga (cost). Efektivitas merupakan hal terpenting dalam pemilihan antibiotika. Antibiotika yang efektif harus aktif terhadap patogen penyebab infeksi dan harus mampu mencapai tempat infeksi dengan konsentrasi yang cukup.
Semua antibiotika mempunyai potensi toksisitas. Efek toksik dapat berupa idiosinkrasi, seperti alergi atau aplasia sumsum tulang disebabkan kloramfenikol, atau kerusakan organ atau jaringan seperti ginjal karena aminoglikosida dan ototoksik oleh amphotericin B. Antibiotika juga dapat mengakibatkan perubahan ekologi mikroba di rumah sakit yang menyebabkan resistensi, suatu masalah yang sering terjadi di ICU.

Masalah biaya (cost) merupakan hal yang juga perlu mendapat perhatian dalam pemilihan antibiotika. Pemilihan antibiotika tidak hanya ditentukan oleh harga obatnya saja (drug acquisition cost) tapi perlu dipertimbangkan biaya pemberian, waktu pemberian, cairan, dan peralatan infus serta biaya monitoring (drug delivery cost). 


\section{Antibiotika Profilaksis}

Antibiotika sering dipergunakan secara profilaksis pada penderita yang dioperasi untuk mencegah infeksi luka dimana diperkirakan kemungkinan akan terjadi atau dimana kalau terjadi infeksi, konsekuensi infeksi akan berat walaupun kemungkinan infeksinya kecil. Sepsis pasca bedah merupakan infeksi nosokomial tersering pada pasien yang mengalami pembedahan. Hal ini merupakan faktor penting yang menambah kesakitan, waktu rawat yang makin panjang, menambah ongkos perawatan dan ketidaknyamanan untuk pasien dan keluarganya.

\section{Identifikasi Penderita Risiko Tinggi Infeksi}

Infeksi luka yang terjadi merupakan interaksi yang kompleks antara inokulasi bakteri kedalam luka selama pembedahan dan daya tahan sistemik tubuh terhadap infeksi. Jumlah bakteri yang terinokulasi mempunyai korelasi langsung dengan risiko infeksi pasca bedah. Tindakan bedah dapat diklasifikasikan sesuai dengan kemungkinan terjadinya kontaminasi luka dan jumlah bakteri yang terinokulasi kedalam luka yaitu luka: clean, clean-contaminated, contaminated, dan dirty (Tabel 1). Angka infeksi pada luka yang clean adalah $1.5 \%$ $3.9 \%$, pada clean-contaminated $3 \%-4 \%$, pada contaminated $8.5 \%$, serta $28 \%$ - $40 \%$ pada dirty wound. Kemungkinan infeksi juga akan meningkat dengan meningkatnya virulensi kuman, begitu pula dengan faktor seperti lama perawatan pra bedah yang panjang, dan penggunaan antibiotika yang berlebihan dengan akibat kolonisasi hospital-acquired pathogen. Perubahan resistensi tubuh terhadap infeksi dapat terjadi secara sistemik atau lokal (didalam luka). Resistensi sistemik terutama ditentukan oleh karakteristik penderita dan keadaan penyakitnya. Dukungan nutrisi dan kontrol infeksi yang jauh akan menurunkan risiko infeksi luka. Pencegahan terhadap resistensi lokal ini merupakan tugas bedah. Beberapa faktor seperti adanya darah, benda asing, iskemi, atau jaringan nekrotik pada tempat operasi dapat menggangu pertahanan lokal serta meningkatkan risiko infeksi. Oleh karena itu teknik operasi yang baik akan menurunkan beberapa faktor risiko tersebut. Manfaat utama pemberian antibiotika adalah mengurangi inokulasi bakteri hidup pada luka operasi. Infeksi dianggap sudah terjadi pada tindakan bedah pada luka yang terkontaminasi atau kotor. Pemberian antibiotika pada keadaan ini lebih dianggap sebagai "terapeutik" untuk infeksi yang dalam daripada profilaksis untuk infeksi luka operasi. Indikasi utama pemberian antibiotika profilaksis pada bidang bedah ini adalah dimana infeksi luka pasca bedah cukup tinggi atau dimana kemungkinan infeksi cukup rendah tetapi konsekuensinya cukup signifikan jika terjadi infeksi. Pemberian antibiotika profilaksis pada pembedahan yang clean-contaminated secara umum dapat diterima. Pemberian antibiotik profilaksis pada kasus bedah yang clean pada awalnya ditujukan pada insersi alat prostetik. Beberapa pedoman prinsip pemberian antibiotika profilaksis dapat dilihat pada tabel 2. Pemilihan antibiotika profilaksis ini juga harus didasarkan pada kemungkinan bakteri yang akan mengkontaminasi luka (Tabel 1).

\section{Antibiotika Terapeutik}

Kebanyakan infeksi dapat diatasi dengan pemberian antibiotika peroral dengan rawat jalan. Tetapi pada keadaan infeksi bedah yang berat terapi harus diberikan antibiotika secara intravena. 
Tabel 1. Antibiotika Profilaksis untuk pembedahan

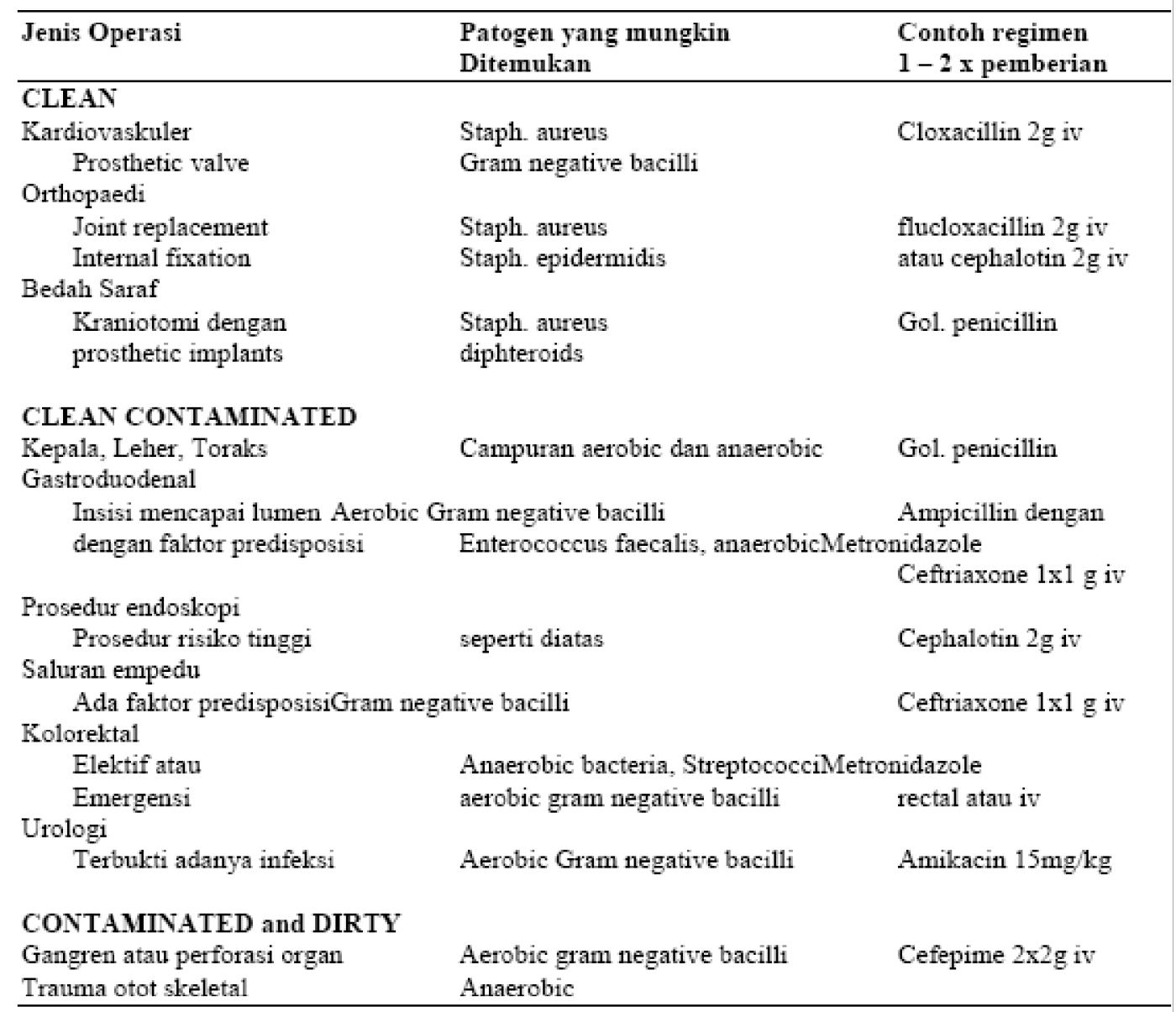

\section{Tabel 2. Prinsip pemberian antibiotika profilaksis}

\. Pilih antibiotika yang efektif terhadap patogen yang kemungkinan akan dihadapi.

a Pilih antibiotika dengan toksisitas rendah.

- Berikan secara tunggal dengan dosis penuh secara intravena 30-60 menit sebelum pembedahan.

a Berikan dosis kedua jika lama operasi melebihi 4 jam atau dua kali waktu paruh antibiotika.

- Berikan dua atau tiga dosis pasca bedah. Tidak perlu diberikan melebihi 24 jam.

a Pemberian antibiotika ini adalah tepat jika infeksi cukup sering atau jika konsekuensi infeksi akan berat.

Awalnya antibiotika dapat diberikan secara empirik karena kita tidak dapat menunggu hasil pemeriksaan mikrobiologi. Terapi antibiotika seharusnya dimulai sebelum didapat hasil kultur pada kasus peritonitis, abses, dan necrotizing soft tissue infection.

\section{Terapi Empirik}

Pemberian antibiotika empirik yang rasional harus memperhatikan mikroorganisme yang biasa terdapat pada tempat infeksi dan pola kerentanan kuman pada rumah sakit atau unitnya (misal: ICU). Infeksi bedah intraabdomen hampir selalu 
Tabel 3. Analisis ekonomi pemberian obat selama 10 hari pada dua alternatif cephalosporin

\begin{tabular}{|c|c|c|}
\hline & $\begin{array}{r}\text { Cefotaxime } 2 \times 1 \\
\text { gram } \\
\text { (dalam rupiah) }\end{array}$ & $\begin{array}{r}\text { Ceftriaxonel x } 1 \text { gram } \\
\text { (dalam rupiah) }\end{array}$ \\
\hline Harga obat (acquisition cost) & 140.660 & 174.930 \\
\hline Total daily acquisition cost & 281.320 & 174.930 \\
\hline \multicolumn{3}{|c|}{ Biaya tiap $1 \mathrm{x}$ pemberian (delivery cost) } \\
\hline - Jasa perawat ${ }^{*}$ & 2.812 & 2.812 \\
\hline - Bahan habis pakai & 6.500 & 6.500 \\
\hline Total daily deliveny cost ${ }^{\mathrm{b}}$ & 18.624 & 9.312 \\
\hline Biaya total per hari ${ }^{a+b}$ & 299.944 & 184.552 \\
\hline Biaya total 10 hari & 2.999 .440 & 1.842 .420 \\
\hline
\end{tabular}

disebabkan oleh infeksi campuran gram negatif dan gram positif aerob dan anaerob. Oleh karena itu pemberian antibiotika awal pada kasus ini harus antibiotika dengan spektrum luas yang mencakup kuman tersebut. Pada kasus pemasangan alat prostetik, bakteri yang berperan umumnya adalah gram positif kokus seperti Staph. aureus dan S. epidermidis, tetapi dapat juga disebabkan oleh kuman gram negatif.

Banyak antibiotika yang tersedia baik untuk pemberian tunggal atau kombinasi. Surgical Infection Society (SIS) mengeluarkan rekomendasi pemberian antibiotika secara empirik pada kasus infeksi intraabdomen, seperti:

$\S \quad$ Tidak memberikan antibiotika seperti cefazolin, cephalosporin generasi pertama, penicillin, ampicilin, erythromycin, dan vancomycin karena obat ini tidak mencakup kuman aerob dan anaerob sekaligus.

$\S$ Metronidazole dan clindamycin sebaiknya tidak diberikan secara tunggal pada infeksi campuran karena kurang aktifitasnya terhadap kuman aerob.

$\S$ Antibiotika lain seperti aminoglycoside, aztreonam, cefuroxime, cefonicid, cefamandole, ceforanide, cefotetan, cefotaxime, ceftizoxime, cefoperazone, ceftriaxone, ceftazidime, dan polymixin sebaiknya tidak diberikan secara tunggal karena cakupan yang kurang adekuat untuk basil gram negatif anaerob.

Antibiotika yang dapat diterima untuk community acquired intraabdominal infection adalah cefoxitin, cefotetan, cefmetazole, dan ticarcilin/clavulanic acid. Tetapi antibiotika ini jangan diberikan jika infeksi intraabdomen ini terjadi di rumah sakit setelah pemberian antibiotika sebelumnya. Untuk infeksi ini dapat diberikan imipenem-cilastatin. Dapat juga diberikan kombinasi metronidazole atau clindamycin ditambah amino glycoside atau antianaerob ditambah cephalosporin generasi tiga atau clindamycin ditambah monobactam. Pertimbangan harga dan toksisitas yang membuat rekomendasi pemberian yang membuat rekomendasi pemberian obat-obat ini lebih disukai dibandingkan dengan kombinasi lainnya.

\section{Terapi Definitif}

Terapi antibiotika harus dirubah setelah diperoleh hasil pemeriksaan pewarnaan gram, kultur, dan sensitivitas. Data sensitivitas dapat menentukan 
antibiotika mana yang sedang dipergunakan tetapi tidak aktif terhadap kuman hasil isolasi. Data ini juga dapat dipergunakan untuk mengganti penggunaan antibiotika dengan antibiotika lain yang kurang toksik atau yang lebih ekonomis.

Infeksi yang berasal dari ICU biasanya disebabkan oleh kuman yang resisten terhadap antibiotika. Ini biasa terjadi pada hospital-acquired Staph. aureus yang sering resisten terhadap methicilin. Vancomycin biasanya diberikan pada kasus MRSA, tetapi jika kuman sensitif terhadap penicillin $G$ atau methicilin maka obat ini sebaiknya yang diberikan karena lebih efektif dan ekonomis dibandingkan dengan vancomycin. Antibiotika yang sering digunakan untuk infeksi oleh $P$. aeruginosa adalah antipseudomonas beta-lactam seperti mezlocilin atau ceftazidime kombinasi dengan aminoglycoside, dengan tujuan untuk mencegah resistensi dan manfaat sinergi obat.

\section{Pemberian Obat}

\section{Cara}

Untuk infeksi bedah yang berat, antibiotika sebaiknya diberikan secara intravena untuk menjamin kadar obat yang adekuat dalam serum. Absorpsi dengan cara lain pada penderita infeksi berat adalah tidak konsisten dimana biasanya pencernaan tidak berfungsi dengan baik. Cara pemberian lain dapat dipakai jika telah terjadi perbaikan.

\section{Lama Pemberian}

Sedikit sekali data yang menjelaskan lamanya pemberian antibiotika yang tepat. Kebanyakan infeksi bedah dapat diterapi dengan efektif dengan pemberian antibiotika selama 5-7 hari. Pada kasus peritonitis, penghentian antibiotika dapat dilakukan setelah terdapat perbaikan klinis, leukosit normal, dan fungsi pencernaan baik. Jika dalam waktu 4-5 hari tidak terjadi perbaikan secara klinis maka perlu dipikirkan kemungkinan kegagalan terapi.

\section{Kegagalan Terapi}

Walaupun sering dianggap bahwa kegagalan respon bakteri terhadap pengobatan adalah karena pemilihan antibiotika yang salah, biasanya ada faktor lain yang berpengaruh. Infeksi intraabdomen yang disertai dengan demam atau leukositosis yang persisten biasanya disebabkan oleh rekuren (tersier) peritonitis atau abses intraabdomen yang memerlukan tindakan drainase. Penyebab demam yang lain misalnya pneumonia, infeksi saluran kencing, infeksi karena infus catheter, drug fever, dan thrombophlebitis.

Mungkin antibiotika yang digunakan juga tidak tepat, dapat berupa antibiotika jenis yang salah, serta cara pemberian dan dosis yang tidak tepat. Bakteri mungkin tidak suseptibel dengan konsentrasi obat pada tempat infeksi atau telah terjadi superinfeksi oleh bakteri lain yang tidak sensistif terhadap antibiotika yang diberikan.

\section{Toksisitas Obat}

Biasanya antibiotika terutama akan diekskresi oleh ginjal dan akan terjadi akumulasi dalam serum pada penderita dengan gangguan fungsi ginjal. Oleh karena itu perlu mengurangi dosis atau penambahan interval pemberian. Obat yang toksik seperti aminoglycoside sebaiknya tidak diberikan pada penderita gangguan ginjal atau kalau diberikan perlu dimonitor kadarnya dalam serum untuk menjamin tidak dicapai kadar toksik. Pada umumnya pemberian antibiotika pada gangguan ginjal adalah 
dengan memberikan $80 \%-100 \%$ dosis pertama, kemudian dosis kedua diberikan sesuai dengan dugaan dosis dan saat pemberian sesuai waktu paruh obat.

\section{Cost (Biaya)}

Pelayanan kesehatan biasanya kurang memperhatikan aspek biaya terapi secara keseluruhan. Sering pemberi layanan kesehatan berfokus kepada aspek finansial yang sederhana, seperti drug acquisition cost, sehingga tidak memperhatikan perbedaan respon klinis dari setiap produk yang dipakai. Padahal, respon klinis yang optimal dapat meningkatkan kepatuhan pasien (compliance), menurunkan jumlah kunjungan ke rumah sakit, menurunkan lama rawat, atau menghindari rawat inap di rumah sakit. Hal ini penting, karena jika tidak diperhatikan, pemberi layanan kesehatan cenderung mengontrol biaya serendah mungkin. Padahal, penekanan biaya semata sering mengorbankan kualitas, sehingga mengurangi kepercayaan pengguna (pasien) terhadap pemberi layanan (dokter dan rumah sakit). Untuk menghindari hal ini, dilakukan analisis farmakoekonomik. Analisis farmakoekonomik dapat mengevaluasi dan membandingkan semua aspek biaya dari terapi yang diberikan.

Dalam pemilihan antibiotika untuk suatu profilaksis ataupun pengobatan, ada tiga faktor yang harus diperhitungkan sebelum memperhatikan faktor biaya. Pertama adalah harus terdapat indikasi klinis yang valid. Kemudian, regimen pemberian harus sesuai, meliputi dosis, frekuensi, dan metoda pemberian. Setelah itu, pemberian obat tidak boleh menyebabkan resistensi bakteri sehingga menyebabkan kegagalan terapi. Apabila semua langkah ini telah diikuti, tetapi kemudian terdapat banyak pilihan antibiotika yang tersedia, barulah faktor biaya memegang peranan. Fokus terhadap biaya saja tanpa memperhatikan indikasi klinis yang terarah sering menyesatkan sehingga menyebabkan kegagalan terapi. Terapi yang gagal menyebabkan bertambahnya biaya perawatan dan obat-obatan sebagai akibat dari komplikasi yang terjadi. Disinilah peranan analisis farmakoekonomik.

Ada 4 metoda analisis farmakoekonomik yaitu cost minimization, cost-benefit analysis, cost-effectiveness analysis, dan cost-utility analysis. Costeffectiveness analysis berasumsi bahwa dana cukup tersedia, kemudian dipilih program dengan biaya minimal. Biaya program dihitung dengan unit moneter, sedangkan hasil akhir di gambarkan dengan pengukuran non-moneter seperti quality of life. Tipe inilah yang cocok digunakan untuk menganalisis profilaksis antibiotika yang paling tepat untuk prosedur bedah.

Terdapat enam faktor biaya yang harus diperhitungkan dalam pemberian antibiotika intravena:

\section{Harga obat (acquisition cost). Harga} ini biasanya berdasarkan harga distributor (HNA). Biaya yang terkait seperti penyimpanan atau transportasi obat dari pabrik sampai ke konsumen tidak diperhitungkan.

\section{Biaya pemberian obat ke pasien} (delivery cost). Ini mencakup biaya tenaga kerja (perawat) untuk mempersiapkan dan menyuntikkan antibiotika ke pasien, dan biaya bahan habis pakai. Biaya jasa perawat dihitung melalui gaji perawat per bulan dibagi dengan berapa jam ia bekerja, kemudian didapat berapa jam sehari ia mengerjakan penyuntikan antibiotika tersebut. Bahan habis pakai antara 
lain kapas, cairan antiseptik, sarung tangan, dan alat suntik. Dengan demikian, antibiotika yang diberikan hanya satu kali per hari akan secara bermakna lebih murah dibandingkan dengan antibiotika yang diberikan dua bahkan tiga kali per hari.

\section{Biaya monitoring laboratorium.}

Meskipun biaya ini kadang tidak mempunyai efek yang bermakna, kadang-kadang dapat sangat mempengaruhi biaya total harian. Misalnya pemberian aminoglikosida memerlukan kontrol laboratorium untuk melihat fungsi ginjal. Biaya ini akan cukup tinggi pada pasien kritis di ICU, karena memerlukan pemeriksaan berulang. Untungnya, pemberian sefalosporin tidak memerlukan monitoring laboratorium seperti demikian.

4. Biaya komplikasi. Komplikasi dari suatu terapi akan sangat meningkatkan biaya, terutama dari memanjangnya waktu perawatan. Komplikasi yang mungkin terjadi sebagai akibat pemberian antibiotika antara lain reaksi alergi, efek hematologis, nefrotoksisitas, ototoksisitas, neurotoksisitas, dan efek gastro-intestinal.

5. Biaya karena terapi yang suboptimal. Biaya yang timbul karena penggunaan antibiotika yang tidak sesuai indikasi ataupun dosisnya cukup sulit untuk dikuantifikasi. Biaya ini meliputi biaya karena meningkatnya resistensi bakteri, memanjangnya waktu perawatan, terjadinya morbiditas yang serius atau bahkan kematian. Memanjangnya waktu perawatan akan berakibat adanya biaya non- pelayanan kesehatan yang ditanggung oleh pasien, antara lain hilangnya waktu produktif pasien dan anggota keluarga, yaitu sesuai dengan expected income dari pasien atau anggota keluarga yang bersangkutan. Adanya tuntutan hukum, meskipun di Indonesia sangat jarang, dapat pula mempertinggi biaya ini.

Pembuangan sampah dan limbah. Meskipun biaya ini pada umumnya sering diabaikan, nilainya dapat cukup bermakna. Contohnya, Kerr et al memperlihatkan bahwa biaya pembuangan bahan habis pakai karena pemberian antibiotika tiga kali sehari selama lima hari adalah 0,78 poundsterling.

Biaya nomor 1 sampai 3 cukup mudah dihitung, tetapi biaya nomor 4 sampai 6 biasanya didapat dari estimasi saja. Contoh perhitungan ekonomi dalam memilih alternatif antibiotika terdapat pada Tabel 3. Dari tabel 3 terlihat bahwa obat yang harganya lebih murah belum tentu menghasilkan biaya keseluruhan yang lebih rendah.

\section{Kesimpulan}

Peranan antibiotika dibidang bedah adalah sebagai terapi tambahan setelah terapi utama pembedahan. Dalam pemberian antibiotika, agar dicapai tujuan eradikasi kuman patogen, harus diperhatikan efektivitas, toksisitas dan harga. Pada pemberian profilaksis, diperlukan pengetahuan yang cukup mengenai pola kuman pada suatu luka operasi. Terapi empirik yang rasional harus memperhatikan mikroorganisme yang biasa terdapat pada tempat infeksi dan pola suseptibilitas kuman pada rumah sakit atau 
unitnya. Faktor biaya tidak ditentukan oleh drug acquisition cost semata, melainkan harus meliputi perhitungan aspek multifaktorial terhadap penggunaan semua sumber daya. Dengan memperhatikan semua aspek pemberian antibiotika yang rasional, akan diperoleh hasil yang memuaskan dokter dan rumah sakit sebagai penyedia layanan kesehatan, dan memuaskan pasien sebagai konsumen.

\section{DAFTAR PUSTAKA}

Antibiotic Guidelines. Antibiotic Guidelines Sub-Committee Victorian Drug Usage Advisory Committee. $7^{\text {th }}$ ed, January 1992.

Gani A. Analisis ekonomi dalam pelayanan bedah. Makalah dibacakan di Muktamar Ahli Bedah Indonesia ke 13, Jakarta 11-14 Juli 1999.

Goldwater SH, Milkovich G. Health Economic Aspects of Parenteral Antibiotic Treatment in the Hospital. Rev Contemp Pharmacother 1995; 6 : 429-434.

Plumridge RJ. Cost of antibiotics: delivery versus acquisition. Spectrum in General Medicine 1998; 1 (1): 1-4.

Pession A, Prete A, Paolucci G. Costeffectiveness of ceftriaxone and amikacin as single daily dose for the empirical management of febrile granulocytopenic children with cancer. Chemotherapy 1997; 43 (5): 358-366.

Rudiman R. Analisis farmakoekonomik: Aplikasi pada Sefalosporin Parenteral untuk Profilaksis dan Terapi Bedah. Medika 2000; 26(5): 303-306.

Smyth ETM, Barr JG, O'Neill CA, Hogg GM. An Assessment of the Hidden and Total Antibiotic Costs of Four Parenteral Cephalosporins. Pharmacoeconomics 1995; 8(6): 541-550. 